\title{
Platinum Nanoparticles Supported on Carbon Nanodots as Anode Catalysts for Direct Alcohol Fuel Cells
}

\author{
S. S Gwebu ${ }^{1}$, P.N Nomngongo ${ }^{1}$, P.N Mashazi ${ }^{2}$, T Nyokong $^{2}$, N.W Maxakato ${ }^{1, *}$ \\ ${ }^{1}$ Department of Applied Chemistry, University of Johannesburg, Doornfontein, 2028, South Africa \\ ${ }^{2}$ Chemistry Department, Rhodes University, Grahamstown, 6139, South Africa \\ *E-mail: nmaxakato@uj.ac.za
}

doi: 10.20964/2017.07.09

Received: 31 January 2017 / Accepted: 2 May 2017 / Published: 12 June 2017

\begin{abstract}
Carbon nanodots (CNDs) were successfully synthesized employing a cheap and green method using oats as a starting material. The Pt/CNDs electrocatalyst was synthesized using carbon nanodots as a reductant and support material without adjusting the $\mathrm{pH}$ of the solution. The synthesized materials were characterized using Fourier transform infrared spectroscopy (FTIR), Brunauer-Emmett-Teller Nitrogen adsorption (BET), X-ray photoelectron spectroscopy (XPS), Transmission electron microscopy (TEM), X-ray diffractometry (XRD) and Inductively coupled plasma optical emission spectroscopy (ICP-OES). The FTIR results proved that the synthesized carbon nanodots contain carboxylic acid functional groups which facilitate the attachment of Pt nanoparticles. The BET surface area for carbon nanodots was found to be $312.5 \mathrm{~m}^{2} \mathrm{~g}^{-1}$ two times higher than that of commercial carbon. XPS results revealed the composition of the materials and the oxidation states of $\mathrm{Pt}$ in $\mathrm{Pt} / \mathrm{CNDs}$ electrocatalyst. TEM images proved that the materials were of the nanoscale. XRD peaks proved that the carbon nanodots were amorphous and $\mathrm{Pt}$ (111) was present in the Pt/CNDs electrocatalyst. ICPOES determined the platinum concentration in Pt/CNDs electrocatalyst to be $8.12 \%$. The electrochemical oxidation of methanol and ethanol were studied by cyclic voltammetry (CV) and chronoamperometry (CA). Cyclic voltammetry results showed that the Pt/CNDs electrocatalyst prepared by this method exhibit superior performance for methanol and ethanol electro-oxidation at room temperature.
\end{abstract}

Keywords: carbon nanodots; electrocatalyst; direct alcohol fuel cells; cyclic voltammetry; chronoamperometry; methanol; ethanol.

\section{$\underline{\text { FULL TEXT }}$}

(C) 2017 The Authors. Published by ESG (www.electrochemsci.org). This article is an open access article distributed under the terms and conditions of the Creative Commons Attribution license (http://creativecommons.org/licenses/by/4.0/). 